\title{
Analysis of Family SMEs Default Risk: the
}

\section{Portuguese Case}

\author{
Inês Lisboa ${ }^{1}$, Magali Costa ${ }^{2}$ and Filipa Santos ${ }^{3}$
}

\begin{abstract}
This work aims to study the default risk of family SMEs (small and medium enterprises) in Portugal, more specifically in the Leiria region. For this purpose, a panel data of 2,658 firms over the period 2012-2017 is analyzed. Using an ex-ante classification of defaulting, results suggest that there are more compliant firms and the number of defaulting firms have decreased over the period analyzed. Then, using a logit regression technique and six variables to predict default obtained through the stepwise methodology, results show that defaulting firms compared to compliant firms are usually younger, with higher difficulties in generating return and in being efficient, and more indebted. The Z'-score model was used as a robustness test, and results suggest that this model is inaccurate to the present reality and this specific sample. Therefore, new coefficients were estimated to increase the model's efficiency. The proposed and the modified Z'-score models have an accuracy of $88.74 \%$ and $85.49 \%$, respectively.
\end{abstract}

JEL classification: G32; G33

Keywords: Family Firms; Default risk; Logistic regression; Stepwise; Panel Data; SME

\footnotetext{
${ }^{1}$ School of Technology and Management (ESTG), Centre of Applied Research in Management and Economics (CARME), Polytechnic Institute of Leiria, Portugal

${ }^{2}$ School of Technology and Management (ESTG), Centre for Advanced Studies in Management and Economics (CEFAGE), Polytechnic Institute of Leiria, Portugal

${ }^{3}$ School of Technology and Management (ESTG), Polytechnic Institute of Leiria, Portugal
} 
Lisboa, Costa \&Santos | Analysis of Family SMEs Default Risk

\section{INTRODUCTION}

The 2008 financial crisis has caused a profound economic contraction that directly or indirectly impacted all sectors and countries (Antão and Moreira, 2018). This crisis has highlighted the need to make timely decisions in order to anticipate, foresee and avoid situations of firm's default or even bankruptcy.

The development of models for predict financial difficulties is not a new topic in the literature. In fact, since the 1960s, a number of works in this field have appeared, such as the studies by Beaver (1966), Altman (1968) and Ohlson (1980). The empirical debate on default/bankruptcy focused mainly on the analysis of financial information through the application of statistical methods, with emphasis on multiple discriminant analysis (MDA) and logistic regression.

However, there are specificities that do not allow the generalization of the default risk models due to firms' singularities (e.g. listed/non-listed, family/non-family firms). Therefore, it is important to establish a prediction model of financial difficulties that can be adapted to each type of firm and that plays an important role in the management and prevention of non-compliance.

This work has two main aims: 1) to explain which signs can be used to identify firms' financial difficulties; 2) to identify the more relevant factors to explain family SMEs probability of default. The intention

is to perform an analysis that allows to predict in advance the signs that may lead to the firm's default of family SMEs. For this, a sample of 2,658 family SMEs (non-financial firms) from Portugal, more specific, Leiria region is analysed from 2012 to 2017.

Several contributions are made to the literature. First, it uses a different methodology to define default. Various authors focus on the legal criterion (e.g. Altman, 1968, Ohlson, 1980, Altman, Iwanicz-Drozdowska, Laitinen and Suvas, 2017). This criterion is an ex-post perspective and firms cannot use this information to avoid bankruptcy. Moreover, the legal criterion is country specific, and it changes over the years. This study uses ex-ante criterion, it means, some indicators that sign firm's financial situation. Works using similar criterion are mainly focused on listed firms (e.g. Pindado, Rodrigues, and Torre, 2008, 2008, Rosner, 2003, Nagar and Sen, 2018, Salloum, Schmitt and Bouri, 2012). Although, the majority of firms all over the world are SMEs, making it relevant to adapt default criteria to this specific group. Thus, in this work ex-ante criterion adapted to SMEs firms were identified to classify firms as default or compliant firms. These criteria not only allow for pre-bankruptcy analysis but can also be applied to firms regardless of whether or not they are listed.

In addition to this, previous studies select one of the known bankruptcy prediction models (e.g. Z-score, O-score) or select several variables to explain bankruptcy. In this study, from the panoply of variables used in the literature, more than twenty ratios, subdivided into seven categories: liquidity, profitability, size, indebtedness, efficiency, cash flows and age, the variables with the highest predictive power of default risk specific to family-type SME were selected, using the stepwise methodology. With this methodology we assure that the selected variables are the more accurate to forecast default situations to a specific group of firms: family SMEs. A new model to explain risk of default, adapted to SMEs, more specifically to family firms, was then created. The validity of this new model was proved, since a robustness test was addressed, using a known prediction model ( $Z$ '-score and its modification adapted to this specific sample) and the success of this new model is higher.

While most studies focus on listed firms, this work studies SMEs that represents $99.9 \%$ of the Portuguese firms (PORDATA, 2019b). Moreover, a specific type of firms is analysed: family firms. The literature about family-owned firms is enriched, as this group is analysed in detailed in this work. Family firms play a key role in the economy. Although, most studies on this topic analyse the influence of property in crisis situations and not which financial variables may impact the default risk. The existing studies on the default risk compare family and non-family businesses, and not try to deeper understand the family group specifically, which is a more homogeneous group with similar characteristics. Therefore, this study contributes to increase the debate about family firms' dynamics.

This work focuses on Portugal, a small-size country that is seldomly analysed. Most studies focus on large-size countries or diverse countries (e.g. Alaminos, Castillo e Fernandez, 2016, Pindado et al., 2008). Portugal is an interesting case study to analyse default topic since after the international financial crisis of 2007/2008, the Portuguese public deficit increased, and the country asked for Troika's help to deal with this problem. From 2011 to 2014 the economic and financial assistance program applied by Troika led to several austerity measures. Firm's mortality rate 
surpasses firm's birth rate from 2008 to 2012. In 2011 the mortality rate was 16\% (around 182021 firms) (PORDATA, 2019c). These numbers call the need to foresee default situations to avoid firm's bankruptcy. A specific region of Portugal is analyzed, Leiria. In 2017 Leiria was the 4th region with the highest value in the Gross Domestic Product indicator per inhabitant (INE, 2019), and it is not one of the largest regions of the country, is the 16th region of the country in terms of size (PORDATA, 2019a). In Leiria region the highest mortality rate was in 2011 with $13.8 \%$ (around 4789 firms), but it was the second region with less mortality rate (PORDATA, 2019d). Moreover, after 2013 (inclusive) firm's birth rate surpass firm's mortality rate.

Finally, the results presented are also relevant for firms, as the variables that need special attention from family SMEs managers are presented. Firms, in order to make timely decisions, can analyse their financial situation in advance and identify signs that could jeopardize their financial health. The findings of this paper may also be helpful to the government in adapting or creating regulations for recovering or revitalizing firms.

This paper is organized into five sections. After this first introductory section, the second one presents a theoretical context, followed by the sample characterization and the description of the methodology and variables to be used in the analysis of default risk. Section four presents and discusses the results obtained. Finally, the main conclusions are presented in the last section.

\section{LITERATURE REVIEW}

Today, every organization is exposed to a set of factors that affect their performance. These factors increase the uncertainty about the return obtained and may lead to situations of default, i.e. situations where cash flows are not enough to meet organization's commitments (Mselmi, Lahiani, and Hamza, 2017). Therefore, financial disruption brings new challenges for managers who must take action to improve organization's performance. Several studies tried to present the best predictive model of default or even bankruptcy in order to support companies' decision making. In fact, since the $1960 \mathrm{~s}$, there have been several works in this field such as Beaver (1966), Altman (1968) or Ohlson (1980).

Some studies use the concepts of default or bankruptcy as the same. However, they are two distinct concepts. Default risk is defined as the probability of the firm not meet its debt responsibilities (Ashraf, Felix, and Lumberjacks, 2019). According to the Insolvency and Corporate Restructuring Code (CIRE - Código de Insolvência e Restruturação de Empresas) (2019), default is a transitory situation that may be related to a lack of liquidity or to the inability to obtain credit. Bankruptcy/insolvency risk refers to the risk that the firm will be unable to comply with obligations that have already been past due or reach a point where its total liability exceeds the total assets (Pindado et al., 2008; Tinoco and Wilson, 2013). When this happens, it is considered that the firm is not economically viable or no longer financially recoverable, i.e. the risk of bankruptcy/insolvency is not a one-off situation, such as the default risk, but rather a permanent one. If a firm is not financially well it does not mean that it is bankrupt, as a firm may be struggling for long periods before going bankrupt (Pindado et al., 2008; Tinoco and Wilson, 2013).

Several studies have attempted to present the best predictive model of default risk to avoid the occurrence of associated (direct and indirect) costs. Although, there are specificities that do not allow the generalization of these models. Thus, it is important to establish a default' prediction model that can be adapted to each country' characteristics and that can be used in the management and prevention of defaults.

\subsection{Criteria}

The literature uses different criteria to classify a firm as default or compliant, which can be subdivided into two groups: studies using the legal classification (also called ex-post classification) or studies using signs that may lead to default (ex-ante).

Several authors use the legal criterion to define default, e.g. Altman (1968), Ohlson (1980), Blums (2003), Martin and Antunes (2012) and Altman et al. (2017). However, financial breakdown analysis based on legal criterion is country specific (Pindado and Rodrigues, 2005) and over the years the legislation changes (Tinoco and Wilson, 2013). 
Lisboa, Costa \&Santos | Analysis of Family SMEs Default Risk

The use of legal classification does not allow a generalization and comparison between firms from different countries. Moreover, the ex-post evaluation is based on firms that are already in a difficult financial situation. Thus, the adoption of an ex-ante criteria makes the detection of default signs possible and allows timely decisions. These criteria keep the focus on the firm's financial problems and not on the legal consequences - bankruptcy. Thus, the probability of a default event happening and not predicting bankruptcy is easier to understand (Pindado and Rodrigues, 2005; Pindado et al., 2008).

Some studies that have used the ex-ante criteria, for instance Pindado et al. (2008), Rosner (2003), Nagar and Sen (2018), Salloum et al. (2012), Lau (1987) and Cheng, Su and Li (2006). Pindado et al. (2008) suggest that listed firms should consider themselves as having financial difficulties when they cumulatively meet the following criteria for two consecutive years: (i) EBITDA lower than financial expenses; (ii) decrease in the firm's market value. Rosner (2003) argues that firms with financial problems have one of the following financial characteristics: (i) negative working capital in the current year; (ii) negative operating result in any of the three years before bankruptcy; (iii) negative retained earnings in the third year prior to default; or (iv) a negative net income in any of the three years prior to default. Nagar and Sen (2018), in addition of Rosner (2003) criteria, also indicate that a firm is in default if it has had negative operating results in the last two consecutive years. Salloum, Schmitt and Bouri (2012) classify a firm in financial difficulty, in a specific year, when the interest coverage ratio is less than 0.8 . The above studies consider two states: default and compliant. However according to Lau (1987) and Cheng, Su and Li (2006) there are five stages of default: stage 0 - financial stability; stage 1 - omission or reduction of dividend payments by more than $40 \%$ over the previous year; stage 2 - technic default and default on loan repayments; stage 3 - protection under bankruptcy law; and stage 4 - bankruptcy and liquidation. As the firm changes its stage, it means that the severity of the situation grew, and thus, firms with financial difficulties are the ones that fall in the stages from 1 to 4.

In Portugal, between 2012 and 2018, the Government established a Company' Recovery System through Extrajudicial Agreements - SIREVE - which consisted of a set of alternative procedures to the process of insolvency with the aim to recover firms through a non-judicial way (SIREVE, 2012). According to the rules of this program, a firm is considered to be in financial health (compliant) when when the following three conditions are cumulatively met: (i) financial capital ratio is higher than 5\%; (ii) earnings before depreciation, amortizations, interest and taxes (EBITDA) is higher than 1.3 of financial expenses; (iii) net debt ratio is between 0 and 10 . Each indicator must be met at least once in the previous three years, and in at least $50 \%$ of the indicators, considering all possible combinations. The indicators applied in SIREVE allow the application to unlisted firms and are more demanding in terms of interest coverage ratio than the criteria previously referred to listed firms.

The effectiveness of the prediction model is verified by validating the classification. Thus, the classification criteria assume an important role in the predictive power of the model. Two types of errors can appear in the firm classification: error Type I, which occurs when a firm in financial distress is incorrectly classified as financially, and error Type II, i.e. when a financially healthy firm is classified as a distress firm (Lin, 2009).

\subsection{Models}

Traditional bankruptcy prediction models are also used to detect the default risk, as these models allow an early detection of possible financial problems (Pindado et al., 2008). Although, there is no model that is globally accepted. In the literature, the most used models are: Univariate Analysis; Z-Score and Zeta models; O-Score (Logit Model); Probit model; Hazard model; D-Score model.

One of the first authors to use ratios to predict bankruptcy was Beaver (1966), who identified six ratios with greater predictive ability of an initial list of thirty ratios. In order to assess the individual performance of each ratio, Beaver (1966) analysed 79 pairs of firms, with data from 1954 to 1964. Each pair consisted of a failed and a non-failed firm with identical characteristics, such as sector and size. The results obtained by the author allowed to correctly classify $87 \%$ of firms a year before bankruptcy and $78 \%$ in an analysis made five years earlier. Beaver's work (1966) introduced important generalizations regarding the performance of ratios and accounting data. However, individual analysis of each ratio can lead to confusing and misread interpretations. 
Due to this limitation multivariate models emerged, to make correlations between the ratios analysed. Altman (1968) developed his model - Z-Score model - based on the Multiple Discriminant Analysis (MDA) statistical model. Altman (1968) selected a sample of 66 listed firms, 33 in each group, and data from the firms' financial statements from 1946 to 1965 . Initially, a list of twenty-two variables divided into five categories: liquidity, profitability, leverage, solvency and efficiency, was used. Note that the selection of variables to include in the model was through statistical significance, correlations between variables and the judgment of the analyst.

Altman's Z-Score model (1968) can only be applied to listed firms, so it has undergone several changes over the years in order to be used by a broader set of firms. According to Altman (1968) the Z-score model is quite accurate regarding bankruptcy prediction, as it has a $95 \%$ success rate for predictions made a year earlier. When the forecast is made two years earlier, the success rate is $83 \%$, and after these two years the success rate decreases. Based on the Z Score model (1968), two versions were developed: Z' Score (1983) and Z' Score (1983). Z' Score (1983) aims to apply the Altman's Z-Score model (1968) to unlisted companies (changing market capitalization by book value), Z' Score (1983) intends to analyse listed companies, whether they are manufactured or not.

Altman, Haldeman and Narayanan (1977) developed the "second generation" Altman's Z-Score model (1968): Zeta model that allows firms to be classified as bankrupt up to five years before bankruptcy and correct the declining success rate for longer periods of the Z-score model. Altman et al. (1977) added in the analysis of listed companies the size effect, the stability of earnings, and the debt service. The authors mentioned several reasons for the construction and analysis of a new model: the change in size and financial profile of bankruptcy firms; the use of update data; the inclusion of not only industrial but also retail firms; the inclusion of changes in financial reporting standards and accounting practices; and the evaluation of the discriminant analysis that occurred after the development of the Z-Score in 1968. Note that Z Score model and Zeta model do not include small companies, namely in the Zeta model, are only included companies whose assets before bankruptcy exceed 20 million.

One of the disadvantages of MDA is related to the difficulty of having non-bankrupt firms with the same characteristics as bankrupt firms (Ohlson, 1980). Therefore Ohlson (1980) suggests the use of logit regression. According to Ohlson (1980) the variables can be aggregated into four categories: a) size; b) leverage; c) performance; and d) liquidity. Ohlson (1980) used a sample of 105 firms that declared bankruptcy and 2,058 non-bankrupt firms. Data was collected between 1970 and 1976. In terms of interpretation, there is no need to define score ranges in this model as required by MDA. Ohlson (1980) achieved a 96\% success rate, which makes his model very accurate.

The use of the Probit model to predict the probability of bankruptcy arises from Zmijewski's study in 1984. The author used a sample of 40 bankrupt listed firms and 800 non-bankrupt listed firms, with data collected from 1972 to 1978. The Probit model shares the same attributes as the Logit model with identical success rates However Probit is harder to apply because it has more complex equations.

The Hazard model was proposed by Shumway in 2001. The author argues that the Hazard model is an appropriate model because it does not provide estimates that may be biased and inconsistent due to the changing of firms' characteristics over the years. According to the author, it is not necessary to choose the explanatory variables for each firm or the period to be analysed. To estimate the Hazard model, Shumway (2001) used a sample of 300 bankruptcy firms with data between 1962 and 1992, and combined accounting ratios with market variables. Shumway (2001) achieved a correct classification of $75 \%$ of failed firms.

Blums (2003) developed a model, which he called D-Score, to estimate the probability of bankruptcy of listed firms. There are three key indicators used by Blums (2003): liquidity, profitability and wealth. In order to test his model, Blums (2003) drew on a sample of 44 firms with financial problems and 1,342 firms without financial problems, gathering financial information from 1990 to 2003. Blums (2003) achieved a success rate of $90 \%$.

Table 1 presents the main determinants of default risk that have been most used in the literature. These can be subdivided into groups: liquidity, profitability, size, leverage, efficiency, financial expenses, and cash flows. The table only presents proxies that use accounting information, and which are used in samples composed of listed or unlisted firms. 
Lisboa, Costa \&Santos | Analysis of Family SMEs Default Risk

Table 1: Determinants of default risk: expected impact, proxies and main studies

\begin{tabular}{|c|c|c|c|}
\hline Variables & $\begin{array}{l}\text { Expect } \\
\text { Impact }\end{array}$ & Proxies & Main References \\
\hline Liquidity & - & $\begin{array}{c}\mathrm{WC}_{\mathrm{t}} / \mathrm{TA}_{\mathrm{t}} \\
\mathrm{CA}_{\mathrm{t}} / \mathrm{CD}_{\mathrm{t}} \\
\mathrm{CA}_{\mathrm{t}} / \mathrm{TA}_{\mathrm{t}} \\
\left.\text { (Cash and Equivalents }{ }_{\mathrm{t}}\right) / \\
\mathrm{CD}_{\mathrm{t}}\end{array}$ & $\begin{array}{l}\text { Alaminos et al. (2016); Altman (1968); Altman et } \\
\text { al. (1977); Altman (1983); Beaver (1966); Cheng } \\
\text { et al. (2009); Gottardo and Moisello (2017); Lin } \\
\text { (2009); Mselmi et al. (2017); Ohlson (1980); } \\
\text { Zmijewski (1984) }\end{array}$ \\
\hline Profitability & - & $\begin{array}{c}\mathrm{OI}_{\mathrm{t}} / \mathrm{TA}_{\mathrm{t}} \\
\mathrm{OI}_{\mathrm{t}} / \mathrm{RVC}_{\mathrm{t}-1} \\
\mathrm{EBITDA}_{\mathrm{t}} / \mathrm{TA}_{\mathrm{t}} \\
\mathrm{RE}_{\mathrm{t}} / \mathrm{TA}_{\mathrm{t}} \\
\mathrm{RE}_{\mathrm{t}-1} / \mathrm{RVC}_{\mathrm{t}-1} \\
\mathrm{NI}_{\mathrm{t}} / \mathrm{TA}_{\mathrm{t}}\end{array}$ & $\begin{array}{l}\text { Alaminos et al.(2016); Altman(1968); Altman } \\
\text { (1983); Altman et al. (1977); Altman and Sabato } \\
\text { (2007); Beaver (1966); Blums (2003); Gottardo } \\
\text { and Moisello (2017); Lin (2009); Lohe and } \\
\text { Calabrò (2017); Martinho and Antunes (2012); } \\
\text { Manzaneque et al. (2016); Pindado et al. (2008); } \\
\text { Ohlson (1980); Shumway (2001); Zmijewski } \\
\text { (1984). }\end{array}$ \\
\hline Size & $+/-$ & $\frac{\log \left(\mathrm{TA}_{\mathrm{t}}\right)}{\operatorname{Ln}\left(\mathrm{TA}_{\mathrm{t}}\right)}$ & $\begin{array}{l}\text { Altman et al. (1977); Donker et al. (2009); } \\
\text { Gottardo and Moisello (2017). }\end{array}$ \\
\hline Leverage & $+/-$ & $\begin{array}{c}\frac{\mathrm{D}_{\mathrm{t}} / \mathrm{TA}_{\mathrm{t}}}{\mathrm{D}_{\mathrm{t}} / \mathrm{E}_{\mathrm{t}}} \\
\mathrm{NCD}_{\mathrm{t}} / \mathrm{TA}_{\mathrm{t}} \\
\mathrm{E}_{\mathrm{t}} / \mathrm{D}_{\mathrm{t}}\end{array}$ & $\begin{array}{l}\text { Alaminos et al.(2016); Beaver (1966); Cheng et } \\
\text { al. (2009); Donker et al. (2009); Gottardo and } \\
\text { Moisello (2017); Lin (2009); Md-Rus et al. } \\
\text { (2013); Mselmi et al.,(2017); Ohlson (1980); } \\
\text { Salloum et al. (2012); Shumway (2001); Tinoco } \\
\text { and Wilson (2013); Udin et al. (2017); Zmijewski } \\
\text { (1984). }\end{array}$ \\
\hline Efficiency & - & $\mathrm{S}_{\mathrm{t}} / \mathrm{TA}_{\mathrm{t}}$ & $\begin{array}{l}\text { Alaminos et al. (2016); Altman(1968); Altman } \\
\text { (1983); Lin (2009); Martinho and Antunes } \\
\text { (2012). }\end{array}$ \\
\hline Interest Expenses & $+/-$ & $\frac{\mathrm{IE}_{\mathrm{t}} / \mathrm{RVC}_{\mathrm{t}-1}}{\mathrm{EBITDA}_{\mathrm{t}} / \mathrm{IE}_{\mathrm{t}}}$ & $\begin{array}{l}\text { Altman et al. (1977); Altman and Sabato (2007); } \\
\text { Manzaneque et al. (2016); Pindado et al. (2008); } \\
\text { Tinoco and Wilson (2013). }\end{array}$ \\
\hline Cash Flow & - & $\mathrm{OCF}_{\mathrm{t}} / \mathrm{D}_{\mathrm{t}}$ & $\begin{array}{l}\text { Beaver (1966); Ohlson (1980); Tinoco and } \\
\text { Wilson (2013). }\end{array}$ \\
\hline \multicolumn{4}{|c|}{$\begin{array}{l}\text { CA- Current Asset; CD - Current Debt; D- Total Debt; E - Equity; EBITDA - Earnings before Interest, Taxes, Depreciation } \\
\text { and Amortization; IE - Interest Expenses; NCD - Noncurrent Debt; NI - Net Income; OCF -Operating Cash Flow; OI - } \\
\text { Operating Income; RVC - Replacement value of capital; RE - Retained Earnings; S - Sales; TA -Total Asset; WC - Working } \\
\text { Capital }\end{array}$} \\
\hline
\end{tabular}

Source: The Authors

\subsection{Family-owned firms}

According to Felicidade (2019), it is estimated that family-owned firms in Portugal represent about $70 \%$ to $80 \%$ of Portuguese firms, contributing about 65\% to the Gross Domestic Product (GDP) and 50\% to employment.

Family-owned firms have characteristics that are specific, and which distinguish them from non-family business. Wielsma and Brunninge (2019) argue that family firms present two identities: one related with the firm and other related with the family, that interact. Family values with a clear objective definition, tend to create an environment of trust and loyalty among employees, suppliers, and consumers, which contributes to the continuity of the company (Miralles, Miralles and Lisboa, 2014). Family-owned firms, therefore, have a long-term orientation with the intention of transferring a healthy business to future generations (Gottardo and Moisello, 2017). In this sense, these firms are more risk-averse, and are only willing to take more risks in order to maintain family's control and to preserve socioemotional wealth (Gómez-Mejía, Haynes, Núñez-Nickel, Jacobson, and Moyano-Fuentes, 2007). 
In the family-owned firms' literature, it is common to refer to agency problems (Donker et al., 2009; Gottardo and Moisello, 2017). According to the literature, the agency costs are lower in family businesses because these firms are usually managed and controlled by the family (Jensen and Meckling, 1976). Felicidade (2019) also mentioned the family business capacity of responding in times of crisis, because family businesses, due to their family values, have greater resilience to negative cycles. In recent years, several studies have been carried out to evaluate and compare family businesses' behavior and performance in financial difficulty situations with non-family businesses (Gottardo and Moisello, 2017; Kristanti et al., 2016; Lohe and Calabrò, 2017).

Gottardo and Moisello (2017) studied the role family-owned businesses in the probability of financial distress in Italy. The authors concluded that family firms are less likely to face difficulties than non-family ones, and the size and number of family members on the board of directors affect the probability of default. These conclusions are identical to those of Donker et al. (2009) who conclude that the higher the level of family participation in management, the less likely it is for firms to suffer financial difficulties. However, Udin et al. (2017) state that the ownership structure has no impact on the firm's probability of default. Lohe and Calabrò (2017) concluded that control can become detrimental during periods of internal financial crisis.

The aforementioned studies aim to analyze the effect of property on the default's probability, comparing family-owned firm and non-family ones.

\section{METODOLOGY}

\subsection{Sample}

The sample is composed of 2,658 Portuguese family firms (non-financial firms) of Leiria region in the period between 2012-2017. Studies in this area for Portugal are scarce, and those that exist mainly analyze listed firms. Although, Portugal is an interesting case study since the international financial crisis of 2007/2008 had great impact in the country. Diverse firms went to bankruptcy, achieving the highest firm's mortality rate in 2011 (around 16\% of total firms) (PORDATA, 2009c). Due to this fact and the increase of public deficit, Portugal asked for Troika's help, and several austerity measures were applied in the country from 2011 to 2014 . This led to a recovery of diverse firms and the country itself.

This work analyzes SMEs, which correspond to about $99.9 \%$ of Portuguese firms (PORDATA, 2019b). A homogeneous group of firms, family-owned, was selected. This group of firms has singularities that distinguish them from non-family firms (Wielsma and Brunninge, 2019). There are also few studies about family-owned firms, but they represent $70 \%$ to $80 \%$ of Portuguese firms (Felicidade, 2019) and about $90 \%$ of the firms in Leiria region (Lisboa, 2019).

Karlsson (2018) argue that family firms are not only relevant to regions, but they are largely impacted by their location. This fact explains the need to explore family firms of one specific region.

The choice of the Leiria region is because it has a relevant role in the country. In 2017, Leiria was the 4th region with the highest value in the Gross Domestic Product indicator per inhabitant (INE, 2019), and it is not one of the largest regions of the country, is the 16th region of the country in terms of size (PORDATA, 2019a). Moreover, Leiria region was the second region with the smallest rate of firm's mortality (PORDATA, 2019d).

The chosen sample period comprises the years 2012 to 2017. 2012 was the year when SIREVE appeared, and the default firm classification criteria defined for this work followed the ones established in this program. 2017 was the last year with available data at the time of data collection.

Firms and their financial data were collected from the SABI database - Iberian Balance Sheet Analysis System database from the Van Dijk Bureau. To restricts the sample to family-owned firms, the criterion defined by SABI was followed. The followed criterion is similar to those used in Kristanti et al. study (2016), and includes firms whose shareholders, whether individual or collective, have a stake of over $25 \%$. There are numerous definitions of family firms and no one is generically accepted (Miralles et al., 2014). The more relevant to define a family firm is the 
Lisboa, Costa \&Santos | Analysis of Family SMEs Default Risk

presence of a family identity and Lisboa (2019) found that in Leiria region this factor is present in the generality of firms that are SMEs with highest levels of capital concentration.

Microenterprises were removed from an initial sample of 10,832 firms (the classification follow the criteria established in the Law Decree n. 81/2017, 2017) because these firms have a higher propensity to introduce anomalous errors and values in the reporting of its financial data (Martinho and Antunes, 2012).

\subsection{Proposed Model}

A Logit model was used in this study, as it has presented a better performance than MDA (Lennox, 1999, Altman and Sabato, 2007 and Pindado et al., 2008). Furthermore, as used in Costa (2016), Pindado and Rodrigues (2005), Pindado, Fernandes and Torres (2006) and Pindado et al. (2008) a panel data methodology was applied, which enables the elimination of unobservable heterogeneity and solves the problem of choosing the estimation year before default. This methodology improves the accuracy of the model.

\subsection{Variables}

\section{Dependent Variable}

An ex-ante approach to define the default firm was followed. The defined criteria were based on SIREVE. Accordingly, the classification criteria to define that a firm is compliant is:

Capital ratio $>5 \%$

Financial Debt / EBITDA $<10$

Financial Debt / EBITDA $>0$

EBITDA $>1.3$ Interests

If more than $50 \%$ of these criteria are not met during the previous 3 years or if at least one of the criteria is not met in the total of these 3 years, the firms are in financial distress.

The dependent variable, to be used in the Logit model, is thus a binary variable that takes the value 1 when the firm is in financial distress and 0 otherwise.

\section{Independent Variables}

To select the independent variables, the most used financial variables were analyzed (see Table 1). Then, the stepwise selection method was used in order to select the variables that best explain the default probability of family SME. A significance level of 5\% was defined for the input of variables and a level of $10 \%$ for their output (Brito and Neto, 2008). Eight variables from six groups were selected. Only the variables of the liquidity group did not present statistical significance to explain the risk of default. After it, a correlation test was performed with the obtained variables to eliminate the variables that provide similar information to explain the behavior of the dependent variable (Brito and Neto, 2008).

The final model is the following:

$$
P=\left(1+\exp \left\{-\left[\beta_{0}+\beta_{1} X_{1}+\beta_{2} X_{2}+\beta_{3} X_{3}+\beta_{4} X_{4}+\beta_{5} X_{5}+\beta_{6} X_{6}+\beta_{7} X_{7}+\beta_{8} X_{8}+\beta_{9} X_{9}\right]\right\}^{-1}\right)
$$

With

$$
\mathrm{X}_{1}=\frac{\mathrm{RE}_{\mathrm{t}}}{\mathrm{TA}_{\mathrm{t}}} ; \mathrm{X}_{2}=\frac{\mathrm{RE}_{\mathrm{t}-1}}{\mathrm{RVC}_{\mathrm{t}-1}} ; \mathrm{X}_{3}=\frac{\mathrm{D}_{\mathrm{t}}}{\mathrm{TA}_{\mathrm{t}}} ; \mathrm{X}_{4}=\frac{\mathrm{D}_{\mathrm{t}}}{\mathrm{E}_{\mathrm{t}}} ; \mathrm{X}_{5}=\frac{\mathrm{NCD}_{\mathrm{t}}}{\mathrm{TA}_{\mathrm{t}}} ; \mathrm{X}_{6}=\frac{\mathrm{S}_{\mathrm{t}}}{\mathrm{TA}_{\mathrm{t}}} ; \mathrm{X}_{7}=\frac{\mathrm{OCF}_{\mathrm{t}}}{\mathrm{D}_{\mathrm{t}}} ; \mathrm{X}_{8}=\operatorname{Ln}\left(\operatorname{age}_{\mathrm{t}}\right) ; \mathrm{X}_{9}=\operatorname{Ln}\left(\operatorname{age}_{\mathrm{t}}\right)^{2}
$$


In which:

D: Debt, E: Equity, NCD: Noncurrent Debt, OCF: Operating Cash Flow, RE: Retained Earnings, RVC: Replacement Value of Capital, S: Sales, TA: Total Asset.

\section{RESULTS}

\subsection{Sample Characterization}

Table 2 summarizes the number of default and compliant firms per year.

Table 2: Firms Classification

\begin{tabular}{ccccc}
\hline \multirow{2}{*}{ Year } & \multicolumn{2}{c}{ Compliant firms } & \multicolumn{2}{c}{ Default firms } \\
& $\mathbf{N}$ & $\mathbf{\%}$ & $\mathbf{N}$ & $\mathbf{\%}$ \\
\hline $\mathbf{2 0 1 2}$ & 2,168 & $81.57 \%$ & 490 & $18.43 \%$ \\
$\mathbf{2 0 1 3}$ & 2,195 & $82.58 \%$ & 463 & $17.42 \%$ \\
$\mathbf{2 0 1 4}$ & 2,197 & $82.66 \%$ & 461 & $17.34 \%$ \\
$\mathbf{2 0 1 5}$ & 2,209 & $83.11 \%$ & 449 & $16.89 \%$ \\
$\mathbf{2 0 1 6}$ & 2,236 & $84.12 \%$ & 422 & $15.88 \%$ \\
$\mathbf{2 0 1 7}$ & 2,257 & $84.91 \%$ & 401 & $15.09 \%$ \\
\hline
\end{tabular}

By the analysis of table 2, we can conclude that the number of default firms is significantly lower than the one of compliant firms. Moreover, the number of default firms decreased over the period analyzed. In 2012 the SIREVE recovery program was implemented, which may have had some impact on this decrease. Moreover, according to the Banco de Portugal (2016) in 2013 the Portuguese economy began to show the first signs of economic recovery, albeit in a moderate way, which can also explain the decrease of default firms.

\subsection{Univariate Analysis}

After the classification of firms as default and compliant firms, the eight variables selected by the stepwise method were analyzed to explain the default risk. Table 3 presents the descriptive statistics, distinguishing between default and compliant firms. The Mann-Whitney Test (MW) nonparametric test was performed to test whether or not the medians for both types of firms are equal.

Table 3: Descriptive statistics

\begin{tabular}{llcccccc}
\hline Variables & Group of firms & Average & Median & $\begin{array}{c}\text { Standard } \\
\text { Deviation }\end{array}$ & Min & Max. & MW test \\
\hline \multirow{2}{*}{ RE/TA } & Compliant & 0.203 & 0.196 & 0.495 & -19.780 & 4.827 & 0.000 \\
& Default & -154.600 & -0.108 & 5103.000 & -182.900 .000 & 1.236 & \\
\hline \multirow{2}{*}{ RE/RVC } & Compliant & 0.180 & 0.141 & 5.258 & -277.600 & 154.900 & 0.000 \\
& Default & -0.518 & -0.045 & 16.790 & -280.700 & 480.600 & \\
\hline D/TA & Compliant & 0.565 & 0.593 & 0.308 & -0.001 & 9.502 & 0.000 \\
& Default & 108.200 & 0.971 & 3549.000 & 0.000 & 127300.000 & \\
\hline D/E & Compliant & 2.558 & 1.366 & 32.310 & -2.534 .000 & 923.400 & 0.000 \\
& Default & 13.940 & 0.860 & 224.400 & -3.290 .000 & 6650.000 & \\
\hline NCD/TA & Compliant & 0.180 & 0.102 & 0.221 & 0.000 & 3.609 & 0.000 \\
& Default & 8.975 & 0.354 & 289.200 & 0.000 & 10358.000 & \\
\hline \multirow{2}{*}{ S/TA } & Compliant & 1.190 & 0.880 & 1.838 & 0.000 & 66.320 & 0.000 \\
& Default & 0.665 & 0.143 & 1.306 & 0.000 & 18.340 & \\
\hline
\end{tabular}


Lisboa, Costa \&Santos | Analysis of Family SMEs Default Risk

\begin{tabular}{llcccccc}
\hline OCF/D & Compliant & 0.960 & 0.107 & 44.120 & -114.400 & 4697.000 & 0.000 \\
& Default & -0.056 & 0.002 & 1.996 & -76.050 & 20.800 & \\
\hline \multirow{2}{*}{ Ln(Age) } & Compliant & 2.680 & 2.773 & 0.750 & 0.000 & 4.852 & 0.000 \\
& Default & 2.473 & 2.565 & 0.822 & 0.000 & 4.575 & \\
\hline
\end{tabular}

D: Debt, E; Equity, NCD: Non-Current Debt, OCF: Operating Cash Flow, RE: Retained Earnings, RVC: Replacement Value of Capital, S: Sales, TA: Total Asset.

The Mann-Whitney test shows that the medians of all variables are different for both groups of firms.

Analyzing the Profitability group (RE/TA and RE/RVC), default firms have negative values, contrary to non-default firms. This result suggests that default firms are unable to generate results and, therefore, have difficulty in fulfilling their obligations. These firms are also more indebted and more dependent on creditors to continue their activity (D/TA, D/E, NCD/TA).

At the efficiency level (S/TA), default firms have lower values than compliant firms suggesting lower efficiency in managing assets. These firms have even fewer operating cash flows (OCF/D). Finally, default firms are proven to be younger than compliant (median 13 vs 16 years).

\subsection{Model}

The proposed model was analyzed in order to verify which variables justify the default situation of family SME. Two variables were eliminated from the initial model: $\mathrm{RE}_{\mathrm{t}-1} / \mathrm{RVC}_{\mathrm{t}-1}$, which is a variable of profitability, and $\mathrm{D} / \mathrm{E}$, which is a debt variable, as they were not statistically significant and the group to which they belong was represented in the model. The results of the model test are shown in the table 4:

Table 4: Results of the final proposed model

\begin{tabular}{|c|c|c|}
\hline & Expect Impact & coefficient \\
\hline const & & $-2.6114 * * *$ \\
\hline RE/TA & - & $-0.5833 * * *$ \\
\hline D/TA & + & $3.0395 * * *$ \\
\hline NCD/TA & + & $0.8360 * * *$ \\
\hline S/TA & $+/-$ & $-0.7798 * * *$ \\
\hline OCF/D & - & $-0.0517 * * *$ \\
\hline Ln(Age) & $+/-$ & $-0.6449 * * *$ \\
\hline $\operatorname{Ln}(\text { Age })^{2}$ & $+/-$ & $0.0967 * * *$ \\
\hline McFadden $\mathbf{R}^{2}$ & & $32.47 \%$ \\
\hline Adjusted R ${ }^{2}$ & & $32.35 \%$ \\
\hline
\end{tabular}

McFadden $\mathrm{R}^{2}$ and Adjusted $\mathrm{R}^{2}$ have a value of approximately $32 \%$. Manzaneque et al. (2016) found a lower McFadden $\mathrm{R}^{2}$, between $11 \%$ and $12 \%$, while Donker et al. (2009) and Udin et al. (2017) found slightly higher values, between $40 \%$ and $48 \%$. Salloum et al. (2012) found dependent variables that justified $72 \%$ of the dependent variable.

The RE/TA variable is statistically significant to explain the default risk and has a negative impact, which is in line with the results obtained by Brito and Neto (2008) and Lin (2009). This means that when retained earnings are not enough to fund the firm's total asset, the default risk increases as firms are not creating funds to meet their obligations. This relation can be age related since younger firms have not had the opportunity to accumulate results (Altman 1968).

Debt variables (D/TA and NCD/TA) contribute to increase default risk probability. Firms need external financing to support their assets and operating activity. Although higher levels of debt increase the firm's financial risk and thus, 
default risk. The results of the D/TA variable are in line with those obtained by Tinoco and Wilson (2013), and those of the NCD/TA variable are like those of Mselmi et al. (2017) and Salloum et al. (2012).

The S/TA variable, an efficiency variable, is also significant at the $1 \%$ level and shows a negative impact, the same was found by Martinho and Antunes (2012). Default firms are not able to manage assets efficiently in the way to increase sales volume. According to Batista (2011), sales tend to fall when firms are in default since the buyers may have afraid that the firm goes to bankruptcy and fails the sales contract. Moreover, the firm may difficulties in doing new investment to follow the market needs.

Analyzing the OCF/ TA variable, it has a significance of $1 \%$, and has a negative impact, which means that the lower the value of this variable, the greater the default risk probability. This result corroborates those found by Tinoco and Wilson (2013). Default firms do not generate enough funds from their operating activity to meet their financial obligations, which leads to situations of distress.

The variables Ln (Age) and Ln (Age) ${ }^{2}$ are both statistically significant and have a U-shaped effect on the default risk probability; that is, until a certain age the default risk decreases and then increases again. This result is contrary to that reported by Costa (2016) which indicated that the effect of age is an inverted U-shape. The results suggest that younger family firms have less experience, less resilience, and, according to Altman (1968), lower accumulated earnings, and so are more likely to default. As family firms gain more experience, greater ability to restructure, and greater value from retained earnings, then their default probability decreases. However, older family firms create resistance to changing old habits, having difficulty to keep up with and adapt to new market trends, which can result in increased risk of default. This difference from previous studies can be due to the type of firms analyzed, because in familyowned firms the knowledge has accumulated over the years and is passed on from generation to generation (Felicidade, 2019), contributing to a more in-depth experience of the business and of the company.

Summing up default firms may not be able to efficiently manage their resources to increase their sales. The lack of resource management capacity coupled with the inability to generate resources from operating activity and the fact that they are less profitable can lead to default firms having to resort to financing to support their assets, leading to an increase in the indebtedness.

\subsection{Success rate}

The predictability of a model is measured by its success rate, namely along with Type I and Type II Errors. Table 5 shows the results obtained.

Table 5: Success rate of final proposed model

\begin{tabular}{|c|c|c|c|c|c|}
\hline & & \multicolumn{2}{|c|}{ Prevision Model } & \multirow{2}{*}{ Total } & \multirow{2}{*}{$\begin{array}{c}\text { Correct } \\
\text { percentage }\end{array}$} \\
\hline & & Compliant & Default & & \\
\hline Actual & Compliant & 12,689 & 211 & 12,900 & $98.36 \%$ \\
\hline Position & Default & 1,521 & 957 & 2,478 & $38.62 \%$ \\
\hline \multicolumn{2}{|c|}{ Total } & 14,210 & 1,168 & 15,378 & $88.74 \%$ \\
\hline
\end{tabular}

The estimated model has a success rate of $88.74 \%$ which is overall a good prediction rate. Comparing the success rate of the original model of Altman Z-Score model (1968), which obtained a 95\% rate, and the Ohlson O-Score (1980), which obtained a rate of $96 \%$, it turns out that our model is slightly below, but very close to these models. The Pindado et al. (2008) model resulted in a success rate of $87 \%$, while Tinoco and Wilson (2013), who estimated three models, found success rates between $80 \%$ and $85 \%$. These models followed an ex-ante approach, as proposed in this study, and have identical success rates. In studies on family-owned firms, Kristanti et al. (2016) obtained a success rate of $78.60 \%$ and Md-Rus et al. (2013), who estimated four models, had rates between $71.90 \%$ and $73.5 \%$.

Looking more closely at the success rate of the model estimated, it classifies better default firms than non-default firms, showing a rate of $98.56 \%$ of the correctly classified, and an Error Type II only of $1.44 \%$. However, only 957 defaulting firms out of 2,478 are correctly classified, which represents a high rate of $61.38 \%$ of Error Type I. 
Lisboa, Costa \&Santos | Analysis of Family SMEs Default Risk

\subsection{Robustness Test}

As a robustness test, the Altman's Z'-Score model (1983) was applied, which is an adaptation of Altman's original ZScore (1968) that can be applied to non-listed firms (contrary to other z-score models). This model, in addition to the groups of default and compliant firms, also defines a third group of firms that are in a "gray zone", which includes firms that there is uncertain whether or not are in financial distress.

The Z'-Score classifies a high number of default firms, varying from $34.65 \%$ to $40.22 \%$ of the total sample, which is double of default firms classified using the ex-ante approach (15.09\% and 18.43\%). For compliant firms, Z'-Score classifies a very small percentage of firms that can meet their obligations, which did not even represent $30 \%$ in any of the six years analyzed. The difference in the percentage of compliant firms between the models can be due to the fact that there are between $37.21 \%$ and $38.53 \%$ firms that, by Z'-Score, are classified as being in a "gray zone", a classification that does not exists in the model proposed in this paper. Results are presented in table 6.

Table 6: Firms' classification: proposed model vs Z'-Score

\begin{tabular}{cccccc}
\hline & \multicolumn{5}{l}{} \\
\cline { 2 - 6 } & Proposed model & $\mathbf{Z}^{\prime}$-Score & Proposed model & $\mathbf{Z}^{\prime}$-Score & Z'-Score \\
\hline $\mathbf{2 0 1 2}$ & $81,57 \%$ & $22,50 \%$ & $18,43 \%$ & $40,22 \%$ & $37,28 \%$ \\
\hline $\mathbf{2 0 1 3}$ & $82,58 \%$ & $23,51 \%$ & $17,42 \%$ & $37,96 \%$ & $38,53 \%$ \\
\hline $\mathbf{2 0 1 4}$ & $82,66 \%$ & $25,32 \%$ & $17,34 \%$ & $36,31 \%$ & $38,37 \%$ \\
\hline $\mathbf{2 0 1 5}$ & $83,11 \%$ & $25,58 \%$ & $16,89 \%$ & $35,97 \%$ & $38,45 \%$ \\
\hline $\mathbf{2 0 1 6}$ & $84,12 \%$ & $25,96 \%$ & $15,88 \%$ & $36,08 \%$ & $37,96 \%$ \\
\hline $\mathbf{2 0 1 7}$ & $84,91 \%$ & $28,14 \%$ & $15,09 \%$ & $34,65 \%$ & $37,21 \%$ \\
\hline
\end{tabular}

Analyzing the percentage of correct classification from default and compliant firms using Z'-Score, it was found that only $27.60 \%$ of the firms were correctly classified. These low rating rates allow us to conclude as reported by Pindado et al. (2008) that models such as Altman's Z-Score (1968) and O-Score (1980) are not adjusted to today's reality, and there is a need to recalculate the coefficients so as to verify if the model's effectiveness increases.

For the recalculation of Z'-Score, logit regression was used instead of the multiple discriminant analysis as did Altman (1983), due to its advantages already described. The function of the modified Z'-Score is as follows (Eq. 2):

Modified $Z^{\prime}-$ Score $=-1.020-0.098 X_{1}-1.872 X_{2}+0.393 X_{3}+-0.003 X_{4}-0.727 X_{5}$

With

$\mathrm{X}_{1}=\frac{\mathrm{WC}_{\mathrm{t}}}{\mathrm{TA}_{\mathrm{t}}} ; \mathrm{X}_{2}=\frac{\mathrm{RE}_{\mathrm{t}}}{\mathrm{TA}} ; \mathrm{X}_{3}=\frac{\mathrm{OI}_{\mathrm{t}}}{\mathrm{TA}_{\mathrm{t}}} ; \mathrm{X}_{4}=\frac{E_{\mathrm{t}}}{D_{\mathrm{t}}} ; \mathrm{X}_{5}=\frac{S_{\mathrm{t}}}{\mathrm{TA}_{\mathrm{t}}}$

In which:

D: Debt, E: Equity, OI: Operating Income, RE: Retained Earnings, S: Sales, TA: Total Asset, WC: Working Capital,

Table 7 shows the success rates of the proposed model, the Z'-Score and the modified Z'-Score. The success rate of the modified Z'-Score is $85.49 \%$ which is much higher than Altman's Z'-Score (1983), and slightly lower than the success rate found by the proposed model. 
Table 7: Modified Z'-Score Success Rate

\begin{tabular}{|c|c|c|c|}
\hline & Proposed model & Z'-score & Modified Z'-score \\
\hline Compliant & $98,36 \%$ & $28,96 \%$ & $98.51 \%$ \\
\hline Default & $38,62 \%$ & $20,89 \%$ & $19.67 \%$ \\
\hline Total & $88,74 \%$ & $27,60 \%$ & $85.49 \%$ \\
\hline
\end{tabular}

\section{CONCLUSIONS}

This paper aims to analyze the default risk in family SMEs, more precisely to understand which variables contribute to increase the default probability of family firms, which is a specific group with an essential contribution to the overall economy. The sample is a panel data of 2,658 family-owned firms from the Leiria region over the period from 20122017.

The study establishes criteria for classifying companies in default or compliant firms, using an ex-ante analysis. The criteria were defined based on SIREVE 2012. The use of this classification led to the conclusion that most of the sampled firms are in a compliant situation. In addition, the number of default firms has been decreasing over the years analyzed, which can be due to the economic recovery felt in Portugal from 2013 to 2017.

A model to detect signs of default risk in advance was then developed and tested. This model was calculated based on the Logit model and includes explanatory variables of profitability, indebtedness, efficiency, cash flows and age. The application of the model shows that default firms are not so profitable as compliant firms, are not creating enough funds to meet their obligations or managing their assets effectively. Moreover, these firms are more indebted than compliant firms. With age, family firms gain more experience and increase their retained earnings which contributes to decrease the risk of default. However, the risk of default increases again for older firms as these firms are often mature firms and find it more difficult to keep up with new market trends, especially family-owned firms that have difficulty in breaking old habits. The proposed model presented a success rate of $88.74 \%$.

After applying the proposed model, a comparison was made with Altman's Z'-Score (1983) model and it was concluded that the coefficients of the original model are out of date in relation to the reality of today taking into account the sample in question. We then decided to recalculate the Z'-Score model but using the logit model. The results obtained were identical to the proposed model, with a success rate of $85.49 \%$. Therefore, we can conclude that the proposed model is more effective for predicting situations of default risk.

Portugal is a country poorly analyzed, particularly in what concerns the risk of default. SME and family-owned firms, which play a key role in the economy, have also been neglected. Most studies in this thematic focus on listed firms regardless of whether or not they are family owned. Thus, this work contributes to the enrichment of the literature by using a sample of firms with have a preponderant role for the Portuguese economy.

The definition of ex-ante criteria that can be applied to SME contributes not only to the literature but also to firms that can use these ratios as a management support tool, helping to control the financial situation and thus avoiding bankruptcy. These firms can realize not only which criteria are important for defaulting, but also which ratios should be analyzed in order to avoid this type of risk. The main conclusion presented in this work can help the government to adapt or create regulations to assist firms in recovery.

Although the main aims of this paper have been met, it is not without limitations. This study only uses financial variables that can be managed by firms in order to present better results to their stakeholders. Moreover, different accounting criteria can be used by firms which mays cause inference in the results. To surpass this situation qualitative variables should be included in future research that could be obtained through interviews and surveys of family business managers.

This work focuses on family-owned firms, which is a homogeneous group. This allows us a deeper knowledge of these type of firms. It would be interesting in future works to compare family firms with non-family ones to see if 
Lisboa, Costa \&Santos | Analysis of Family SMEs Default Risk

there are significant differences in these two groups of firms. In this case, ownership and control variables could be included to assess their impact on the probability of default risk.

Finally, it is suggested that in the future to apply the proposed model and the default risk classification criteria to different regions of Portugal, or even in other countries to understand the similarities and differences.

\section{REFERENCES}

Alaminos, D., Del Castillo, A., and Fernandez, M. A. (2016). A global model for bankruptcy prediction. PLoS ONE, 11(11), 1-18. https://doi.org/10.1371/journal.pone.0166693

Altman, E. I. (1968). Financial Ratios, Discriminant Analysis and the Prediction of Corporate Bankruptcy. The Journal of Finance, 23(4), 589-609. https://doi.org/10.1111/j.15406261.1968.tb00843.x

Altman, E. I. (1983). Corporate financial distress: a complete guide to predicting, avoiding, and dealing with bankruptcy. New York: Wiley Interscience, John Wiley and Sons.

Altman, E. I., Haldeman, R. G., and Narayanan, P. (1977). ZETA Analysis - A new model to identify bankruptcy risk corporations. Journal of Banking and Finance, 1, 29-54. https://doi.org/10.1016/0378-4266(77)90017-6

Altman, E. I., Iwanicz-Drozdowska, M., Laitinen, E. K., and Suvas, A. (2017). Financial distress prediction in an international context: a review and empirical analysis of Altman's Z- Score model. Journal of International Financial Management and Accounting, 28(2), 131-171. https://doi.org/10.1111/jifm.12053

Altman, E. I., and Sabato, G. (2007). Modelling credit risk for SMEs: Evidence from the U.S. market. Abacus, 43(3), 332-357. https://doi.org/10.1111/j.1467-6281.2007.00234.x

Antão, M. G., and Moreira, C. P. (2018). Eficiência dos modelos multissectoriais de previsão de falência empresarial: o caso do sector terciário ibérico. Lusíada Economia and Empresa, 24, 91-114.

Ashraf, S., Félix, E. G. S., and Serrasqueiro, Z. (2019). Do Traditional Financial Distress Prediction Models Predict the Early Warning Signs of Financial Distress? Journal of Risk and Financial Management, 12, 1-17. https://doi.org/10.3390/jrfm12020055

Banco de Portugal, E. (2016). Relatório de estabilidade financeira - novembro 2016. Lisboa. Disponível em https://www.bportugal.pt/sites/default/files/anexos/pdfboletim/ref_11_2016_pt.pdf

Beaver, W. H. (1966). Financial Ratios as Predictors of Failure. Journal of Accounting Research, 4, 71-111. https://doi.org/10.2307/2490171

Blums, Martins (2003). D-Score: Bankruptcy Prediction Model for Middle Market Public Firms. Available online: http://www.minneapolisfed.org/mea/contest/2004papers/blums.pdf (accessed on 5 December 2016)

Brito, G. A. S., and Neto, A. A. (2008). Modelo de classificação de risco de crédito de empresas, Revista Contabilidade and Finanças, 19(46), 18-29. https://doi.org/10.1590/S1519$\underline{70772008000100003}$

Cheng, W.-Y., Su, E., and Li, S. J. (2006). A financial distress pre-warning study by fuzzy regression model of tse-listed companies. Asian Academy of Management Journal of Accounting and Finance, 2(2), 75-93.

Cheng, W.-Y., Su, E., and Li, S.-J. (2009). Corporate governance and financial distress: evidence from public- listed electronics companies in Taiwan. Journal of Statistics and Management Systems, 12(5), 813-827. https://doi.org/10.1080/09720510.2009.10701424 
Costa, M. P. (2016). Three Essays on Firms' Financial Distress. PhD Thesis. Évora University Código da Insolvência e da Recuperação de Empresas (CIRE). Decreto Lei 53/2004 de 18 de março. Diário da República $\mathrm{N}^{\mathrm{a}}$ 66/2004. Acedido a 24 jan. 2019. Disponível em http://www.dre.pt

Decreto-Lei no 81/2017 da Economia. (2017). Diário da República: I Série No 125/2017. Disponível em http://www.dre.pt

Donker, H., Santen, B., and Zahir, S. (2009). Ownership structure and the likelihood of financial distress in the Netherlands. Applied Financial Economics, 19(21), 1687-1696. https://doi.org/10.1080/09603100802599647

Felicidade, M. (2019). Gestão RH em Empresas Familiares. RH Magazine, 121, 14-17.

Gomez-Mejía, L. R., Haynes, K. T., Núñez-Nickel, M., Jacobson, K. J., and Moyana-Fuentes, J. (2007). Socioemotional Wealth and Business Risks in Family-Controlled Firms: Evidence from Spanish Olive Oil Mills. Administrative Science Quartely, 52, 106-137. https://doi.org/10.2189/asqu.52.1.106Gottardo, P., and Moisello, A. M. (2017). Family firms, risk-taking and financial distress. Problems and Perspectives in Management, 15(2), 168 177. https://doi.org/10.21511/ppm.15(2-1).2017.01

Jensen, M. C., and Meckling, W. H. (1976). Theory of the firm: Managerial behavior, agency costs and ownership structure. Journal of Financial Economics. 3(4), 305-360. https://doi.org/10.1016/0304-405X(76)90026-X

INE. (2019). Produto Interno Bruto por habitante. Lisboa, Portugal: INE, Instituto Nacional de Estatística.

Karlsson, J. (2018). Does regional context matter for family firm employment growth? Journal of Family Business Strategy, 9, 293-310. https://doi.org/10.1016/j.jfbs.2018.08.004

Kristanti, F. T., Rahayu, S., and Huda, A. N. (2016). The Determinant of Financial Distress on Indonesian Family Firm. Procedia Social and Behavioral Sciences, 219, 440-447. https://doi.org/10.1016/j.sbspro.2016.05.018

Lau, A. H.-L. (1987). A Five-State Financial Distress Prediction Model. Journal of Accounting Research, 25(1), 127-138. https://doi.org/10.2307/2491262

Lennox, C. (1999). Identifying failing companies: a re-evaluation of the logit, probit and DA approaches. Journal of Economics and Business, 51(4), 347-364. https://doi.org/10.1016/S0148-6195(99)00009-0

Lin, T.-H. (2009). A cross model study of corporate financial distress prediction in Taiwan: Multiple discriminant analysis, logit, probit and neural networks models. Neurocomputing, 72, 3507-3516. https://doi.org/10.1016/i.neucom.2009.02.018

Lisboa, I. (2019). Sucessão nas empresas familiares e o impacto no endividamento. Evidência para as PME da região de Leiria. Revista de Gestão dos Países de Língua Portuguesa, 17(2), 24. https://doi.org/10.12660/rgplp.v17n2.2018.78223

Lohe, F.-W., and Calabrò, A. (2017). Please do not disturb! Differentiating bord tasks in family and non-family during financial distress. Scandinavian Journal of Management, 33(1), 3349. $\mathrm{h}$ https://doi.org/10.1016/i.scaman.2017.01.001

Manzaneque, M., Priego, A. M., and Merino, E. (2016). Corporate governance effect on financial distress likelihood: Evidence from Spain. Revista de Contabilidad, 19(1), 111-121. https://doi.org/10.1016/j.rcsar.2015.04.001

Martinho, R., and Antunes, A. (2012). Um Modelo De Scoring Para As Empresas Portuguesas. Banco de Portugal - Relatório de Estabilidade Financeira, 117-131. 
Md-Rus, R., Mohd, K. N. T., Latif, R. A., and Alassan, Z. N. (2013). Ownership Structure and Financial Distress. Journal of Advanced Management Science, 1(4), 363-367. https://doi.org/10.12720/joams.1.4.363-367

Miralles, J., Miralles, M., and Lisboa, I. (2014). "The Impact of Family Control on Firm Performance. Evidence From Portugal and Spain”. Journal of Family Business Strategy, 5(2), 156-168. https://doi.org/10.1016/j.jfbs.2014.03.002

Mselmi, N., Lahiani, A., and Hamza, T. (2017). Financial distress prediction: The case of French small and medium-sized firms. International Review of Financial Analysis, 50, 67-80. https://doi.org/10.1016/j.irfa.2017.02.004

Nagar, N., and Sen, K. (2018). Earnings Management Strategies During Financial Distress. The IUP Journal of Accounting Research and Audit Practices, 17(3), 52-79.

Ohlson, J. A. (1980). Financial Ratios and the Probabilistic Prediction of Bankruptcy. Journal of Accounting Research, 18(1), 109-131. https://doi.org/10.2307/2490395

Pindado, J., and Rodrigues, L. (2005). Determinants of Financial Distress Costs. Financial Markets and Portfolio Management, 19(4), 343-359. https://doi.org/10.1007/s11408-005-6456-4

Pindado, J., Rodrigues, L., and de la Torre, C. (2006). Estimating the Probability of Financial Distress: International Evidence, 1-34. https://doi.org/10.2139/ssrn.485182

Pindado, J., Rodrigues, L., and de la Torre, C. (2008). Estimating financial distress likelihood. Journal of Business Research, 61(9), 995-1003. https://doi.org/10.1016/j.jbusres.2007.10.006

PORDATA. (2019a). Dimensão por Região. Lisboa, Portugal: PORDATA, Fundação Francisco Manuel dos Santos.

PORDATA. (2019b). Número de PME. Lisboa, Portugal: PORDATA, Fundação Francisco Manuel dos Santos.

PORDATA. (2019c). Taxa de natalidade, mortalidade e sobrevivência das empresas. Lisboa, Portugal: PORDATA, Fundação Francisco Manuel dos Santos.

PORDATA. (2019d). Taxa de natalidade, mortalidade e sobrevivência das empresas não financeiras por região. Lisboa, Portugal: PORDATA, Fundação Francisco Manuel dos Santos.

Rosner, R. L. (2003). Earnings Manipulation in Failing Firms. Contemporary Accounting Research, 20(2), 361-408. https://doi.org/10.1506/8EVN-9KRB-3AE4-EE81

Salloum, C., Schmitt, C., and Bouri, E. (2012). Does board structure affect financial distress? A study with reference to family firms in Lebanon. Investment Management and Financial Innovations, 9(4), 113-123.

Sistema de Recuperação de Empresas por Via Extrajudicial (SIREVE). Decreto Lei 178/2012 de 3 de agosto. Diário da República N ${ }^{\mathrm{a}}$ 150/2012. Acedido a 24 jan. 2019. www.dre.pt.

Shumway, T. (2001). Forecasting Bankruptcy More Accurately: A Simple Hazard Model. The Journal of Business, 74(1), 101-124. https://doi.org/10.1086/209665

Tinoco, M. H., and Wilson, N. (2013). Financial distress and bankruptcy prediction among listed companies using accounting, market and macroeconomic variables. International Review of Financial Analysis, 30, 394-419. https://doi.org/10.1016/i.irfa.2013.02.013

Udin, S., Khan, M. A., and Javid, A. Y. (2017). The effects of ownership structure on likelihood of financial distress: an empirical evidence. Corporate Governance: The International Journal of Business in Society, 17(4), 589-612. https://doi.org/10.1108/CG-03-2016-0067

Wielsma, A., and Brunninge, O. (2019). "Who am I? Who are we?" Understanding the impact of family business identity on the development of individual and family identity in business families. Journal of Family Business Strategy, 10, 38-48. https://doi.org/10.1016/i.jfbs.2019.01.006 
AABFJ | Volume 15, No.4, 2021

Zmijewski, M. E. (1984). Methodological Issues Related to the Estimation of Financial Distress Prediction Models. Journal of Accounting Research, 22, 59-82. https://doi.org/10.2307/2490859 